\title{
Foraging Behavior of Major Apis Species on Coriander
}

\author{
Kapil Sharma $^{1 *}$, Balraj Singh ${ }^{2}$, N.K. Meena ${ }^{2}$ and R.S. Meena ${ }^{2}$ \\ ${ }^{1}$ Mahatma Jyoti Rao Phoole University, Jaipur, Rajasthan-302019, India \\ ${ }^{2}$ National Research Centre on seed spices, Ajmer, Rajasthan-305006, India \\ *Corresponding author
}

\section{A B S T R A C T}

\section{Keywords \\ Foraging rate, $A$. mellifera, $A$. dorsata, A. florea \\ Article Info \\ Accepted: \\ 20 December 2017 \\ Available Online: \\ 10 January 2018}

Investigation was carried out during Rabi, 2014-2015 at Research Farm National Research Center on Seed Spices, Tabiji, Ajmer (Rajasthan). Objective of the study is to investigate the foraging behavior of major Apis species on coriander. The maximum foraging rate of $A$. mellifera was recorded at $14.00 \mathrm{~h}$ (13.6 umbels visited $\mathrm{min}^{-1}$ and 3.10 plant/five minutes) followed by Apis dorsata at $12.00 \mathrm{~h}$ (10.66 umbels visited $\mathrm{min}^{-1}$ and 2.80 plants/five minutes). And Apis florea at $14.00 \mathrm{~h}$ (9.80 umbels visited $\mathrm{min}^{-1}$ and 2.55 plants/five minutes).

\section{Introduction}

Coriander (Coriandrum sativum Linn.) is an annual herbaceous plant, belongs to the family Apiaceae (Umbelliferae). It is also popularly known as 'Dhania' in north India, 'Dhana' in Bengal, 'Dhaniyalu' in Andhra Pradesh and 'Kathamalli' in Tamil Nadu (Evans et al., 2002). Its origin is considered to be Europe to southwestern Asia. It is cultivated as a winter season annual crop. It can be grown in all types of soil under a wide range of climatic conditions but cool climate and dry weather is required during the maturity of crop. Coriander is mainly grown in various countries like India, Morocco, Romania, France, Spain, Argentina, Italy, Egypt, Russia, Iran, Canada and Australia. Among these countries, India is the largest producer, consumer as well as exporter country in the world.

Coriander is a highly cross pollinated nature of crop, allowed a large population of insect pollinators during flowering for their pollination. A number of insects are responsible for pollination in various ways. It includes a number honeybee's species i.e. Apis florea, Apis mellifera, Apisdorsata along with many Hymenopteran (Deodikar and Suryanarayana, 1977; Shelar and Suryanarayana, 1981; Baswana, 1984), syrphids (Chaudhary and Singh, 2007) and other dipteran flies, moths and butterflies, many unidentified hymenopteran and natural enemies like Coccinellids and Chrysoperla. 
Among the various reasons for low yield, insufficient pollinators during blooming are to be considered as one of the major limiting factor for lowering the production per unit area. Honeybees are to be considered as major pollinators of coriander crops in semi-arid region of Rajasthan play a major role in enhance the quality of coriander.

\section{Materials and Methods}

The present investigation was conducted at the institute's farm, NRC on Seed Spices (ICAR), Tabiji, Ajmer-305206 (Rajasthan) during Rabi season of 2014-15. The site is situated in mid part of Rajasthan. The center is located on $74^{0}$ $35^{\prime}$ ' 39" to $74^{\circ} 36^{\prime}$ ' $01^{\prime \prime}$ " East longitude and $26^{\circ}$ 22 ' 12 " to $26^{\circ} 22$ ' 31 " North latitude at an altitude of $460.17 \mathrm{~m}$ above mean sea level at Ajmer district of Rajasthan. The region falls under agro climatic zone III of Rajasthan.

The climate of this zone is typically semi-arid and sub-tropical characterized by mild winter and moderate summers and associated with relatively high humidity during the months of July-September. The mean annual rainfall is $590 \mathrm{~mm}$, mostly received from south-west monsoon during the last week of June to October.

Weather, the non-monetary input influence the growth, yield and quality of crops as well as biotic phase of soil during the growing season, hence it is important to present climatic variables in this context. The mean weekly meteorological observations were recorded during the crop period from the meteorological observatory of the farm and also depicted in Figure 1. Data revealed that during coriander cropping season, maximum temperature was ranged from $18.3^{0} \mathrm{C}$ to $35.8^{0}$ $\mathrm{C}$ whereas, minimum temperature ranged from 5.1 to $24.6^{0} \mathrm{C}$ during Rabi season of year 2014-15, respectively.

The experiment was laid out in factorial randomized block design with four replications and six treatments. The treatments including: $\mathrm{T}_{1^{-}}$without insect pollination (caged), $\mathrm{T}_{2^{-}}$open pollination, $\mathrm{T}_{3^{-}}$Jaggery solution (10\%), Bee pollination with Apis mellifera -Caged, $\mathrm{T}_{4}$ - Sugar solution (10\%), $\mathrm{T}_{5}$ - Jaggery solution (10\%) and T6- Organic control (Organic salt 5ml/lit.)

\section{Foraging rate of Apis species}

Foraging rate of the Apis foragers under observations was studied by counting the number of umbels visited per minute and in addition, the number of plants visited by the Apis species per minute was also recorded. These observations were taken during different times $(06.00$ to $18.00 \mathrm{~h})$ at full blooming conditions of the crop in open conditions from all four replications.

\section{Results and Discussion}

\section{Foraging rate of Apis species}

The foraging rate of different honeybee species in coriander flowers was carried out to know the quantitative pollinator's status, their activities and foraging potential of honeybees on the crop for maximum pollination. The data were recorded at two hourly interval on foraging rate (the number of umbels visited by foragers minute ${ }^{-1}$ and the number of plants visited by foragers $\mathrm{hr}^{-1}$ ) of Apis pollinators during winter season 2014-15 and have been presented in table 1-3.

A. florea started foraging on coriander at $08.00 \mathrm{~h}\left(0.10\right.$ bees $\left.\mathrm{m}^{2}\right)$, its population increased abundantly and reached to maximum from 10.00 to $14.00 \mathrm{~h}$ (19.0-23.1 bee $\mathrm{m}^{2}$ ) and then declined slowly to cease completely by $18.00 \mathrm{~h}$. The population of $A$. mellifera was not seen till $08.00 \mathrm{~h}$ on coriander in winters and then appeared at low level $\left(3.9\right.$ bees $\mathrm{m}^{2}$ ) by $09.00 \mathrm{~h}$, subsequently 
increased to peaked from 12.00-14.00 h (14.3 to 17.0 bees $\mathrm{m}^{2}$ ), and then again declined to negligible $\left(0.10\right.$ bees $\left.\mathrm{m}^{2}\right)$ at $18.00 \mathrm{~h}$. $A$. dorsata was also started foraging at $09.00 \mathrm{~h}$ with low level, which gradually increased to its maximum level at $12.00 \mathrm{~h}$ (7.19).

The mean foraging rate was higher in $A$. mellifera (5.0) than A. dorsata (3.92) and $A$. florea, (2.91). Initially, A. mellifera was not observed on coriander flowers till $07.00 \mathrm{~h}$ because low temperature and fog water deposited on the floral parts but its population increased latterly. The maximum foraging rate of A. mellifera was recorded at $14.00 \mathrm{~h}$ (13.6 umbels visited $\left.\mathrm{min}^{-1}\right)$. Similarly, the average 1 plant and maximum 3.10 plants were visited by this species in each five minutes (Table 1).
The foraging rate of $A$. dorsata was not recorded up to $07.00 \mathrm{~h}$, on coriander crop, which initiated $(0.05)$ at $08.00 \mathrm{~h}$ and become highest at $12.00 \mathrm{~h}$, where 10.66 umbels visited $\mathrm{min}^{-1}$ by this species. Similarly, the average 1.07 plants and maximum 2.80 plants of coriander were visited in each five minutes by A. dorsata during clear and sunny days in winters (Table 2). The average foraging rate of Apis florea was recorded lower (2.91) than A. mellifera and $A$. dorsata, however, this species was more abundant on coriander. The maximum foraging rate of A. florea $(9.80$ umbels visited $\left.\mathrm{min}^{-1}\right)$ was noticed at $14.00 \mathrm{~h}$ and then declined at low level at $18.00 \mathrm{~h}(0.02$ umbels visited $\min ^{-2}$ ). Similarly, the average 0.93 plants and maximum 2.55 plants of coriander were visited in each five minutes by A. florea during $14.00 \mathrm{~h}$ (Table 3).

Table.1 Mean foraging rate of Apis mellifera Linn. on coriander under OP conditions

\begin{tabular}{|c|c|c|}
\hline Time of Visits(hrs) & No. of umbels visited $\left(\mathbf{m i n}^{-\mathbf{1}}\right)$ & No. of plants visited/five minutes \\
\hline $\mathbf{6 : 0 0}$ & $0.0^{*}$ & 0.00 \\
\hline $\mathbf{8 : 0 0}$ & 0.1 & 0.02 \\
\hline $\mathbf{1 0 : 0 0}$ & 6.2 & 1.50 \\
\hline $\mathbf{1 2 : 0 0}$ & 10.7 & 2.20 \\
\hline $\mathbf{1 4 : 0 0}$ & 13.6 & 3.10 \\
\hline $\mathbf{1 6 : 0 0}$ & 3.9 & 0.20 \\
\hline $\mathbf{1 8 : 0 0}$ & 0.5 & 0.00 \\
\hline Mean & 5.0 & 1.0 \\
\hline
\end{tabular}

*Mean of four replication; OP- Open pollination

Table.2 Mean foraging rate of Apis dorsata Fab. on coriander under OP conditions

\begin{tabular}{|c|c|c|}
\hline Time of Visits(hrs) & $\begin{array}{c}\text { No. of umbels visited } \\
\left(\mathbf{m i n}^{-\mathbf{1}}\right)\end{array}$ & $\begin{array}{c}\text { No. of plants visited/five } \\
\text { minutes }\end{array}$ \\
\hline $\mathbf{6 : 0 0}$ & $0.0^{*}$ & 0.00 \\
\hline $\mathbf{8 : 0 0}$ & 0.05 & 0.01 \\
\hline $\mathbf{1 0 : 0 0}$ & 6.10 & 2.00 \\
\hline $\mathbf{1 2 : 0 0}$ & 10.66 & 2.80 \\
\hline $\mathbf{1 4 : 0 0}$ & 7.13 & 1.60 \\
\hline $\mathbf{1 6 : 0 0}$ & 2.50 & 1.00 \\
\hline $\mathbf{1 8 : 0 0}$ & 1.0 & 0.10 \\
\hline Mean & 3.92 & 1.07 \\
\hline
\end{tabular}

*Mean of four replication; OP- Open pollination 
Table.3 Mean foraging rate of Apis florea Fab. on coriander under OP conditions

\begin{tabular}{|c|c|c|}
\hline Time of Visits(hrs) & No. of umbels visited $\left(\mathbf{m i n}^{-\mathbf{1}}\right)$ & No. of plants visited/five minutes \\
\hline $\mathbf{6 : 0 0}$ & $0.00 *$ & 0.00 \\
\hline $\mathbf{8 : 0 0}$ & 0.10 & 0.10 \\
\hline $\mathbf{1 0 : 0 0}$ & 2.18 & 1.05 \\
\hline $\mathbf{1 2 : 0 0}$ & 5.63 & 1.20 \\
\hline $\mathbf{1 4 : 0 0}$ & 9.80 & 2.55 \\
\hline $\mathbf{1 6 : 0 0}$ & 2.56 & 1.60 \\
\hline $\mathbf{1 8 : 0 0}$ & 0.12 & 0.02 \\
\hline Mean & 2.91 & 0.93 \\
\hline
\end{tabular}

*Mean of four replication; OP- Open pollination

The foraging rate of different honeybee species in coriander flowers was carried out to know the quantitative pollinator's status, their activities and foraging potential of honeybees on the crop for maximum pollination.

The mean foraging rate was higher in $A$. mellifera (5.0) than A. dorsata (3.92) and $A$. florea, (2.91). Initially, A. mellifera was not observed on coriander flowers till $07.00 \mathrm{~h}$ because of low temperature and fog water deposited on the floral parts but its population increased latterly. The maximum foraging rate of $A$. mellifera was recorded at $14.00 \mathrm{~h}$ (13.6 umbels visited $\mathrm{min}^{-1}$ ). Similarly, the average 1 plant and maximum 3.10 plants were visited by this species in each five minutes. The similar results obtained in the study carried out by Choudhary and Singh (2007) and Kant et al., (2013) who reported the foraging rate of Apis cerana (15.2), A. mellifera (13.1) and Episyrphus balteatus (7.8) and other hymenopterans on coriander crop. Sushil et al., (2013) also reported that the more honeybee foragers visited broccoli followed by kohlrabi and finally Chinese cabbage with $6.05,5.35$ and 5.05 bees/plant, respectively are partially agreement with present results.

The maximum foraging rate of A. mellifera was recorded at $14.00 \mathrm{~h}$ (13.6 umbels visited $\left.\min ^{-1}\right)$. Similarly, the average 1 plant and maximum 3.10 plants were visited by this species in each five minutes. The foraging rate of $A$. dorsata was not recorded up to $07.00 \mathrm{~h}$, on coriander crop, which initiated $(0.05)$ at $08.00 \mathrm{~h}$ and become highest at 12.00 $\mathrm{h}$, where 10.66 umbels visited $\mathrm{min}^{-2}$ by this species.

Similarly, the average 1.07 plants and maximum 2.80 plants of coriander were visited in each five minutes by $A$. dorsata during clear and sunny days in winters. Synage (1947) reported the maximum foraging frequency of $A$. mellifera from 11.00 to $15.00 \mathrm{~h}$ whereas, for $A$. cerana, was shorter by 2 hours from 11.00 to $13.00 \mathrm{~h}$ and $A$. dorsata peaked from 10.00 to $12.00 \mathrm{~h}$ are accordance with the present findings.

Waheb and Ebadah (2011) was also reported the major bee pollinator and maximum activities of $A$. mellifera between 12.00 to $14.00 \mathrm{~h}$.

The maximum foraging rate of A. florea $(9.80$ umbels visited $\left.\mathrm{min}^{-1}\right)$ was noticed at $14.00 \mathrm{~h}$ and then declined at low level at $18.00 \mathrm{~h}(0.02$ umbels visited $\left.\min ^{-2}\right)$. Similarly, the average 0.93 plants and maximum 2.55 plants of coriander were visited in each five minutes by A. florea during $14.00 \mathrm{~h}$. 
The average foraging rate of Apis florea was recorded lower (2.91) than A. mellifera and $A$. dorsata, however, this species was more abundant on coriander.

\section{References}

Baswana, K.S. 1984. Screening of coriander germplasm against chalcid fly (Systole albipennis). Annals of Applied Biology Supplement: Tests of Agrochemicals and Cultivars, 104: 114 - 115.

Chaudhary, O.P. and Singh, J. 2007. Diversity, temporal abundance, foraging behavior of floral visitors and effect of different modes of pollination on coriander (Coriandrum sativum L.). J. of Spices and Aromatic Crops, 16: 8-14.

Deodikar, G. B. and Suryanaryana, M. C. 1977. Pollination in the service of increasing farm production in India. Adv. Pollen Spore Res. 2: 67-87.

Evans, W.C., Trease and Evans. 2002. Pharmacognocy Fifteenth International edition, W.B. Saunders, Edinburgh,
London, New York. 262.

Kant, K., Singh, B., Meena, S.R., Ranjan, J.K., Mishra, B.K., Solanky, R.K. and Kumar M. 2013. Relative abundances and foraging behavior of honey bee Species on minor seed spice crops, International J. Seed. Spices 3(2): 51-54.

Shelar, D.G. and Suryanarayana, M.C. 1981. Preliminary studies on pollination of coriander (Coriandrum sativum L.). Indian Bee J.43: 110-111.

Sushil, S.N., Stanley, J., Hedau, N.K., and Bhatt, J.C. 2013. Enhancing seed production of three Brassica vegetables by honey bee pollination in north-western Himalayas of India. Universal Journal of Agricultural Research, 1: 49-53.

Synge, A.D. 1947. Pollen collection by honey bees (Apis mellifera). J. Anim. Ecol. 16: 122-138.

Wahab, A.T.E. and Ebadah, I.M.A. 2011. Impact of honeybee and other insect pollinators on the seed setting and yield production of black cumin. Nigella sativa L. J. Basic. Appl. Sci. Res., 1(7):622-626.

\section{How to cite this article:}

Kapil Sharma, Balraj Singh, N.K. Meena and Meena, R.S. 2018. Foraging Behavior of Major Apis Species on Coriander. Int.J.Curr.Microbiol.App.Sci. 7(01): 2928-2932. doi: https://doi.org/10.20546/ijcmas.2018.701.350 